\title{
Impact of Stakeholder Psychological Empowerment on Project Success
}

\author{
Herry Pintardi Chandra ${ }^{1}$, Indarto ${ }^{1}$, I Putu Artama Wiguna ${ }^{1}$, and Peter F. Kaming ${ }^{2}$
}

\begin{abstract}
The relationship between psychological empowerment of stakeholders and project success is an important thing that must be known by project manager. This research developed and tested the model to predict how well the impact of stakeholder psychological empowerment on project success. Stakeholder psychological empowerment was defined to have five indicator variables covering intrinsic motivation, opportunity to perform, ability to perform, task behaviors, and contextual behaviors. Meanwhile, project success can be measured by cost performance, time performance, quality performance, profitability, and customer satisfaction. In this study, it was hypothesized that stakeholder psychological empowerment influenced project success. Based on the data obtained from a questionnaire survey carried out to 204 respondents, structural equation modeling (SEM) was used for predicting the performance of project success. It was found that stakeholder psychological empowerment influenced project success, especially on the ability to perform of stakeholders.
\end{abstract}

Keywords—stakeholder psychological empowerment, project success

Abstrak-Hubungan antara keberdayaan psikologis pemangku kepentingan dan keberhasilan proyek adalah sesuatu yang penting yang harus diketahui oleh manajer proyek. Penelitian ini mengembangkan dan mentest model untuk memprediksi seberapa baik pengaruh dari keberdayaan psikologis pemangku kepentingan dalam keberhasilan proyek. Keberdayaan psikologis pemangku kepentingan dibatasi pada lima variabel indikator yang meliputi motivasi intrinsik, peluang mengerjakan, kemampuan mengerjakan, perilaku tugas, dan perilaku kontekstual. Sementara itu, keberhasilan proyek dapat diukur dengan kinerja biaya, kinerja waktu, kinerja kualitas, keuntungan, dan kepuasan konsumen. Hipotesis dalam penelitian ini adalah: keberdayaan psikologis pemangku kepentingan berpengaruh terhadap keberhasilan proyek. Berdasarkan data yang diperoleh dari kuesioner terhadap 204 responden, digunakan model persamaan struktural (SEM) untuk memprediksi kinerja keberhasilan proyek. Dari penelitian didapatkan bahwa keberdayaan psikologis pemangku kepentingan berpengaruh terhadap keberhasilan proyek, khususnya pada kemampuan mengerjakan dari pemangku kepentingan.

Kata Kunci-keberdayaan psikologis pemangku kepentingan, keberhasilan proyek

\section{INTRODUCTION}

$\mathrm{M}$ ost projects have a wide range of associated stakeholders whose interests, expectations, and needs can influence the project shape or progress to a greater or lesser extent. Stakeholders tend to make major sources of uncertainties in projects. Effective project management involves understanding these sources of uncertainties because stakeholder related uncertainty can lead to project failure. They can influence a project success at different stages of project life cycle and its implication. Therefore, the psychological empowerment among stakeholders influences the project success. Fawcett et al. in [1] proposed that empowerment as the process of gaining influence over events and outcomes of importance to an individual or group contributes to the project success. Empowerment is the granting to teams or individuals the power and authority to do their jobs. It means realising organization members to use their total capabilities - all of their knowledges along with their personal influence to reach the objectives. Empowerment can be used to provide the resources necessary to meet customer's needs [2].

Herry Pintardi Chandra, Indarto, and I Putu Artama Wiguna are with Department of Civil Engineering, FTSP, Institut Teknologi Sepuluh Nopember, Surabaya, 60111, Indonesia. Email: herrypintardi@gmail.com, indarto@ce.its.ac.id, artama@ce.its.ac.id.

Peter F. Kaming is with Department of Civil Engineering, Universitas Atma Jaya, Yogyakarta, 55281, Indonesia. Email: kaming@staff.uajy.ac.id.
In relation to that, project managers who represent the owners should understand the influence of stakeholder psychological empowerment on project success. It is the reason of why this study was held.

Stakeholders are persons or organizations (e.g., customers, sponsors, the performing organization, or the public), who are actively involved in the project or whose interests may positively or negatively affect the performace or completion of the project. The project manager such as the owners' representative must manage the influence of the various stakeholders in relation to the project requirements to ensure a successful outcome [3].

The objectives of this study were to identify the model that explained the influence of stakeholder psychological empowerment on project success. This research developed and tested the model to predict how well the impact of stakeholder psychological empowerment on project success. In the best project performance, managing the stakeholder psychological empowerment was a key focal point. This paper reported the main findings of the research and presented the emergent framework to be used for further research.

Some authors in special issues noted that knowledge on stakeholder management needs to be further investigated [4]. Rowlinson and Cheung identified stakeholder typologies and adopted multi-perspective views of project performance in order to link the relations among management, stakeholders and sustainability in a framework by allowing the exploration of project and its 
success. Their paper presented an emergent model of stakeholder management that identified project contextual factors, perceptions, empowerment and relations among management processes as determinants of project success $[1,4]$. Walker et al. in recommended that hard project skills (centred on time, cost, quality) and soft management skills (stakeholder identification, management, and engagement as key project management skills) could reduce the chances of project failure and enhance success through having cleared pictures of stakeholder influence patterns [4]. Mathur et al. found that considering sustainability as a subjective goal which could be interpreted in a particular context through a dialogue with the context-specific stakeholder presented a meaningful and promising way to pursue sustainability [5].

\section{A. Stakeholder}

Project stakeholders can generally be divided into two groups, the first is direct project stakeholders which include project sponsors, project owners, project designers, contractors, sub contractors, or material suppliers who are directly involved in the execution of the project. The second is indirect project stakeholders, that are not directly involved in the execution of the project, but can have an influence on project execution, and this includes regulatory agencies or authoroties, professional associations, general public, labor unions, local government departments, media, lobbyist, national industry, police and other emergency services[3]. Stakeholders that will be analyzed in this research is direct stakeholders. Olander and Landin [6] suggested that attitudes of stakeholders and understanding of complexity of stakeholder influences were important factors in the planning and location of facilities of the project. In fact, stakeholder may differ in their personalities, needs, demographic factors, and past experiences, or they may find themselves in different physical settings, time periods, or social surroundings [7]. Rowlinson and Cheung bulit a model of effectiveness and incorporated the key elements in order to investigate how management relations could affect perceptions of project outcomes by making empowerment of stakeholders. The outcomes of project could be measured by the response of attitudes, commitment, motivation, and satisfaction of stakeholders [1].

\section{B. Stakeholder Psychological Empowerment}

Psychological empowerment is a constellation of experienced cognitions manifested as sense of meaning, competence, impact, and self-determination (Conger and Kanungo, Spreitzer, Thomas and Velthouse cited in [8]). Psychological empowerment can be explained by intrinsic motivation, opportunity to perform, ability to perform, task behaviors, and contextual behaviors [8]. Performance has been viewed as a function of motivation and ability (Vroom in [8]), opportunity to perform [8], task performance behaviors [8,9], and contextual performance behaviors [8,9]. Motivation is the inner state that causes an individual to behave in a way that ensures the accomplishment of some goals [2]. Motivational factors are conditions that tend to motivate stakeholders when they exist, but their absence is rarely strongly dissatisfying [7]. Intrinsic motivations are internal rewards that a person feels when performing a job, so there is a direct and often immediate connection between work and rewards [7], where psychological empowerment is significantly related to intrinsic motivation [8]. Also, opportunity to perform will partially mediate the positive relations between psychological empowerment and both task and contextual performance behaviors. This factor is measured by the availabilities of job-related information, tools, equipment, materials, budgetary support, time, adequate trainning, and statutory regulations [8]. While, ability to perform is operationalized with item by ability, experience, training, and knowledge [8], and generally accepted that the product of knowledge and one's skill in applying it constitute the human trait [7]. Furthermore, task behaviors are measured by cognitive ability, job knowledge, task proficiency, and experience [9], formal job performance, responsibility of job description [8]. Moreover, contextual behaviors are identified as job dedication, and interpersonal facilitaties [9]. Job dedication can be measured by extra hours to get work done on time, paying close attention to important details, work harder than necessary, exercising personal dicipline and self-control [8], perseverance and persistence in pushing artisan, dedication in helping artisan, commitment towards overall project objectives [9]. Interpersonal facility behaviors are identified as praising team members when they are successful, supporting or encourage the team members with a personal problem, treating team members fairly [8], effective time management on all project sites, providing timely information for artisan ability to arrive at effective solution to conflict while maintaining good relationship [9].

Practically, by clearly showing that psychological empowerment exhibits positive performance behaviors, emerges as a valuable path in the search for performance improvement in project settings, however it still require cooperation and good teamwork [8]. Tuuli and Rowlinson suggested that motivation, ability, and opportunity to perform have important managerial implications for the competence of project organizations. The organizational psychology theory of job performance provides a potentially useful framework for adoption in project based-sectors of the construction industry. It can be used to predict the performance of project managers [9].

\section{Project Success}

A project is a temporary endeavor undertaken to create a unique product, service, or result. The temporary nature of project indicates a definite beginning and ending, and has social, economic, and environmental impacts that far outlast the projects themselves. Unique means the work needed to produce the product, or service, or whatever, is different in some distinguishing ways from other products, or services, or what so ever. A project can create a product that can be either a component of another item or an end of item in it self, a capability to perform a service, or a result such as an outcome or document. In order to reach the project 
success, project managers should select appropriate processes required to meet the project objectives, use a defined approach that can be adopted to meet the requirements, and comply with requirements to meet the stakeholder's needs and expectations. In additions, they should be able to balance the competing demands of scope of time, cost, quality, resources, and risk to produce the specific product [3].

Kerzner suggested that the definition of project success was modified to include completion within the allocated time period, within the budgeted cost, at the proper performance or specification level accepted by customer, with minimum or mutually agreed upon scope of changes, without disturbing the main work flow of the organization, and without changing the corporate culture [10]. Pinto and Slevin in [11] found the following 10 factors affecting the success of a project: project mission and goals, top management support, project planning, client consultation, personnel issues, technical issues, client acceptance, project control, communication, and troubleshooting. The traditional concept to measure a project success was indicated by punctual time completion, budget precision, and qualifications which meet stakeholders' expectations [12, 13].

The criteria for success were in fact much wider, incorporating the performance of the stakeholders, evaluating their needs and expectations [13]. It is common knowledge that project success can be reached when the interests of the key stakeholders or even of all stakeholders should be taken into account. However, the important thing to reach project success is not only identifying the stakeholders but also understanding the role the stakeholder may play. Stakeholder is any group or individual who can affect or is affected by the achievement of the project objectives [14]. A successful project measurement system is required to reflect the needs and expectations of all the stakeholders. Stakeholders'performance need to be measured and assessed throughout the project phases in order to ensure that no conflict, disputes, and blaming syndromes has occured by the time the completion stage is reached [13]. The importance of the stakeholders in relation to the construction project performance is the real success factors of construction projects [13]. They also highlighted the difference between the success criteria and success factors. Success factors contributed to achieve success on project, while success criteria determined how the success or failure of a project would be judged. Key Performance Indicators (KPIs) is factors constituting the success criteria which are helpful to be used to compare the actual and estimated performance in terms of effectiveness, efficiency, and quality of both workmanship and product. Kagioglou et al. in [13] proposed that the performance of suppliers in construction projects generally was poorly covered. Successful stakeholders' performance has to be measured and managed in order to ensure their continual participation and cooperation in a construction project.

Other researchers suggested that in addition to the measurement of time, budget, quality, customer satisfaction, the overall stakeholders' satisfaction should be considered [12]. The five most frequently used criteria to measure project success include technical performance, efficiency of execution, managerial and organizational implications, personal growth and manufacturer's ability, and business performance [12]. Shenhar et al. in [15] proposed that project success was divided into four dimensions : project efficiency, impact on customer, business success, and future preparation. Furthermore, project efficiency is the degree to which organizational resources contribute to production, it is doing things right [3], and impact on customer is the important influence on customer that can be assessed after a short time. Meanwhile, business success is the aim of the organization that can be measured after a significant level of sales has been achieved. In additions, future preparation is the planning of the organization that can only be determined three to five years after project completion. Lin and Mohamed in [15] suggested that project success can be viewed from macro viewpoint and micro viewpoint. Macro viewpoint can be assessed by completion of time, cost, quality, performance, and safety. Furthermore micro view point can be assessed by completion of time, satisfaction, utility, and operation.

Ling et al. believed that project operational performance to reach project success could be found by project related factors, project procedures, human related factors, and external environment [16]. Furthermore, they explained that project related factors covered schedule performance, while project procedures involved budget performance. Meanwhile, human related factors and external environment compressed profitability and owner satisfaction and public satisfaction.

Considering these implications of research on project success, this study attempt to assess the project success based on cost performance, time performance, quality performace, profitability performance, and customer satisfaction performance.

Cost is defined as the degree to which the general conditions promote the completion of a project within the estimated budget [15]. Cost is an important measurement to reach project success. Therefore project cost management should incorporate the processes required to ensure that the project is completed within the project budget. These processes include resource planning, cost estimating, cost budgeting, and cost control. Resource planning involves determining what resources and what quantities of each should be used to perform project activities. Cost estimating involves developing an approximation of the cost of resources needed to complete the project activities. Cost budgeting means allocating the project cost estimate of project packages or elements of the project. Cost control involves controlling of changes to the project budget which includes monitoring to ensure cost performance to detect variances from the plan, to ensure that all appropriate changes are recorded accurately in the cost baseline [17]. Cost is not only confined to the sum stated in the tender only, it is the overall cost that a project incurs from inception to completion, so this includes any cost arising from variations, and legal claims [15]. According to Park's research, various factors of project cost depended on project budget estimate precision, adequate tender sum, price competition, overbudget 
possibility, cost effectiveness, severity of variations, long-term profitability, rapid decision making, competitive tendering process, and cash flow certainty [18].

Time is duration for completing the project, while scheduling is the conversion of the planned activities into a calendar-related plan. To identify the difference between planning and scheduling, a project manager shall refer to the sequenced work required to reflect the scope of the project, and set against a calendar time frame. Naoum and Chan in [15] suggested that time could be measured in terms of construction time, speed of construction and time overrun. Meanwhile, Park [18] explained that various factors influencing project time included fixed construction period, rapid decision making, overrun duration, project time constraints, adequacy of time, government regulation constraints, lack of time, service life planning, ground condition constraints, severity of variations.

Quality is defined as the totality of characteristics of an entity that bears its ability to satisfy stated or implied needs, as the totality of features required by a product or services to satisfy a given need, fitness for purpose [3, 15]. They further stated that the product quality was the guarantee of the products that convinced the customers or the end-users to purchase or use. In construction world, quality should be related to the specifications that building is built accordingly. In additions, to achieve the specifications, technical performance was extended with scope and category were reqiured [15]. Meanwhile, Park stated that quality can be viewed from design quality plan, material quality, construction quality plan, contracted work quality, durability of building assemblies, determination of construction quality, durability of building components, level of technology, conformance to requirement, and adequate labor skills [18].

Profitability is defined as the amount of total revenue that exceeds the total costs of producing the products sold. In general, profitability standards indicate how much money a company or an organization would like to make as profit over given period-that is, its return on investment [2]. Therefore, management should set objectives that specify the profit the company would like to generate. Alarcon and Ashley defined value of profit that can be evaluated from the owner satisfaction, the realization of the product quantity produced, the cost of maintenance and operatons, and the flexibility of business benefit [15]. Furthermore, Park stated that profitability is one of the elements of shareholder's satisfaction [18]. Profitability can be shown from return on investment (ROI) that is calculated as profit after taxes divided by total assets [2].

Customer satisfaction is a customer's positive or negative feelings about the value that is received as a result of using a particular organization's offering in specific situations. These feelings can be immediately reaction to particular situation or an overall to a series of situation experiences [19]. In addition to that, these may include the different ideals perception of customers, what other competitors offer, marketing promises, other product categories, and industrial norms. Whereas satisfaction is defined as condition of what customer's perceive is the same or more than what they expect. Therefore, customer satisfactory survey should identify project specific measurement, product, advisers, suppliers and contractors, and defects [20]. Woodruff and Gardial argued that satisfaction was interrelated with customer's values, and there were three categories of variables that can be measured: satisfactory drivers, global satisfactory feelings, and satisfactory outcomes [19]. There is a distinct relationship between customer satisfaction and customer survey. Here is a seven step approach to developing a successful customer service system: total management commitment; knowing the customers; standards of service quality performance development; staff recruitment and training, and service quality accomplishment rewards; maintaining close relationship to the customers; and working towards continuous improvement [21].

\section{METHOD}

The survey method was adopted to test the hypotheses proposed in this study. A questionnaire survey was designed for respondents to assess the performance of a project they had participated in and to evaluate the influence of stakeholder psychological empowerment on project success. A five - point scale (described as $1=$ incompetent, 2 = weak, $3=$ fair, $4=\operatorname{good}, 5=$ outstanding) was used where respondents were presented with some questions on relevant indicators of stakeholder psychological empowerment influencing the project success in the question sheet and they were asked to give responses. (See Figure 1 and Table 1). Selection of the indicators was highly significant in the context of a true measurement of the representative practices across the laten variables of stakeholder psychological empowerment and project success being used in structural equation modeling (SEM). The questionnaire was then developed consisting of questions that inquired the variables that measure the laten variables. Each question was associated with variables described in the preceding sections. The first part of questionnaire was designed to assess stakeholder psychological empowerment level by evaluating the psychological empowerment of stakeholder, which covered intrinsic motivation, opportunity to perform, ability to perform, task behaviors, and contextual behaviors. While the second part of questionnaire assessed project success that was influenced by stakeholder psychological empowerment and there were 5 variabel indicators; cost performance, time performance, quality performance, profitability, and customer satisfaction.

The data collected from the respondents were analyzed by using a software package called AMOS 16, a structural equation modeling (SEM) tool. The SEM is a statistical technique that combines a measurement model (confirmatory factor analysis or CFA) and a structural model (regression or path analysis) in a single statistical test [22]. It is a family of statistical models that explain the relationships among multiple variables. In doing so, it examines the structure of interrelationships expressed in a series of equations, similar to a series of multiple 
regression equations. These equations depict all of the relationships among construct involved in the analysis [23].

In the SEM process, a theoretical model was initially specified that incorporated the latent variables represented by their constituent variables and their relationships. The data obtained from 204 respondents was then validated through CFA. The initial model in Figure 1 shows that project success was influenced by stakeholder psychological empowerment as suggested by most researchers (e.g.[1, 4-6, 8-9]) and this was in line wih the hypothesis we assumed.

The questionnaire was conducted in different ways : via email, hand delivered, and face to face interviews to 204 respondents involved mostly in construction project. The target population of the survey in this study was owners, construction management consultants, designer consultants, contractors, sub contractors or suppliers. Among the 204 respondents, 45 were owners, 13 were construction management consultants, 30 were designer consultants, 97 were contractors, and 19 were subcontractors or suppliers (See Table 2). Meanwhile, out of 204 respondents, $38.73 \%$ were mostly medium management, $33.82 \%$ top management, and $27.45 \%$ lower menagement (See Table 3). Then, most of them were working between 10-20 years of experience $(46.57 \%)$. Few were working in more than 20 years of experience $(29.40 \%)$, and even fewer were working in less than 10 years experience $(24.03 \%)$. Based on National Construction Services Development Board, contractor participants in this study were divided into three groups: gred $5(46.39 \%)$, gred $6(22.68 \%)$, and gred $7(30.93 \%)$.

Based on a substantial amount of theory, the researcher proposed the following relationship H1: Stakeholder psychological empowerment influenced on project success.

\section{RESULTS AND DisCUSSION}

The assessed model and all loading factors were found to be significant at $\alpha=0.05$, and the Cronbach's Alpha of the all model was found to be greater than 0.70 (0.829). All of the validation and reliability results can be seen in Table 4.

Cronbach's Alpha measurement of reliability that range from 0 to 1 , with value of 0.60 to 0.70 that it is the lower limit of acceptability [23]. All coefficients of validation test ( $\mathrm{r}$ value test) were found to be greater than 0.140 (critical value $r$ for sample size $n=204$ and at $\alpha=$ $0.05)$. It means that the latent variables are represented quite well by their constituent variables. Cronbach's Alpha coefficients of all variables were well over the 0.70 , minimum value suggested by Nunally in [22] and this indicated that the internal reliability of the constructs were quite high. The Cronbach's Alpha coefficients were 0.741 for stakeholder psychological empowerment , and 0.796 for project success.

\section{A. Confirmatory Factor Analysis (CFA)}

The results of CFA stakeholder psychological empowerment can be shown in Figure 2. Among the five variable indicators, ability to perform was found to be the greatest influencing factor on stakeholder psychological empowerment (with standardized coefficient $=0.656$ and squared multiple correlation $=$ 0.430). It means that ability to perform has a great influence or significantly related to stakeholder psychological empowerment. As explained by Podsakoff's suggestion in [8], the ability to perform was mediator in the empowerment - performance relationship. It partially mediated the positive relationship between psychological empowerment and both task behaviors and contextual behaviors. The results of goodness of fit measurement supported the proposed measurement model. The Chi-square / $\mathrm{DF}=2.691$ (critical value $2.00-5.00$ ), TLI $=0.911$ (cut off value $\geq$ 0.900 ), $\quad$ CFI $=0.956$ (cut off value $\geq 0.900$ ), and RMSEA $=0.091$ (cut off value $\leq 0.08$ ) indicated that overall of the model was fit.

The results of CFA project success can be shown in Figure 3. Among the five variable indicators, quality performance was found to be the greatest influencing factor on the project success (with standardized coefficient $=0.783$ and squared multiple correlations $=$ $0.614)$. It means that quality performance has a great influence or significantly related to project success. Similarly, Toor and Ogunlana in [12] suggested that quality performance can be used as a guide to measure the success of a project together with time performance and cost performance as iron triangle. This finding is in line with Park's research that constructed asset should have at least a minimum standard of quality and all participants should be encouraged to design building with better quality materials [18]. The result of goodness of fit measurement supported the proposed measurement model. The Chi-square / $\mathrm{DF}=4.896$ (critical value 2.00 5.00 ), $\mathrm{TLI}=0.869$ (cut off value $\geq 0.900$ ), $\mathrm{CFI}=0.935$ (cut off value $\geq 0.900$ ), and RMSEA $=0.139$ (cut off value $\leq 0.08$ ) indicated that overall the model was fit.

\section{B. Structural Model Analysis}

Figure 4 shows the final SEM with standardized solutions and the error terms. As seen, all of the path coefficients were positive and significant at $\mathrm{p}<0.05$, thus this model has a good performance. The final SEM results suggested that stakeholder psychological empowerment has a significant influence on project success with path coefficient of 1.00. And this hypothesized that stakeholder psychological empowerment had a strong influence on the project success. This finding is in line with the previous findings that focused on stakeholder empowerment and engagement and utilized these to explain how a relationship management approach can generate both a sense of group empowerment and project success [1]. The other researcher argued that the concept of employee empowerment has emerged as a key to engendering the performance of individuals and teams [8].

As seen in Figure 4 the goodness of fit index measurement for project success was satisfactory. The ratio of $\mathrm{CMIN} / \mathrm{DF}=3.855$ or less than 5.00 indicated that the model was fit. Furthermore, all of other essential indices such as Tucker Lewis Index $(\mathrm{TLI})=0.769$, and comparative fit index $(\mathrm{CFI})=0.820$ provided evidence 
that the measurement model and the data were acceptable. The nonnormed fit index (NNFI) or TLI considers a correlation for model complexity [22]. The comparative fit index (CFI) was interpreted in the same way as the TLI and represented the relative improvement in fit of the hypothesized model over the null model. Tolarable range of TLI and CFI is 0 to 1 where 0 indicates no fit and 1 indicates perfect fit. The Root Mean Square Error of Approximation (RMSEA) is an estimate of the discrepancy between the observed and estimated covariance matrices in the population [23]. The value of RMSEA is $=0.119$ (cut off value $\leq 0.08$ ). The reason why the indexes are not closer to perfect fit (are not higher than 0.90 for TLI and CFI) can be explained by the amount of sample size used in this study and by the fact there may be more than one variable laten stakeholder psychological empowerment that influences the project success. In additions, goodness of fit indexes are affected by sample size, where a larger sample size can influence the value of chi - square. For more information about CMIN and baseline comparisons value, it can be seen in Table 8 and Table 9. From Table 5, it can be shown that all of $\mathrm{p}$ value were or less than 0.05 which indicated that all variables were significantly related to measure their laten variables. All Ctitical Ratio (CR) value were greater than 2.00 showing that all variables were significantly related to measure the laten variables.

Table 6 shows that variable indicator ability to perform (x14) had the largest coefficient (0.575) correlated to stakeholder psychological empowerment, and quality performance (x19) also had the largest coefficient (0.742) correlated to project success. From these findings, project managers such as owner's representatives should be aware of how their employee's ability to perform contributes to reach project success by making a good quality of the construction product. When individuals felt empowered, proactive behaviors such as flexibility, resilience, and persistence ensued [8]. This is the responsibility of the project managers and each direct stakeholder that involved in the project execution. Meanwhile, intrinsic motivation (x12) was the variable of stakeholder psychological empowerment that had the second largest coefficient (0.523). In many work situation, however, persons who are motivated are capable of successfully accomplishing their tasks [8]. Whereas time performance (x18) was the variable of project success that had the second largest coefficient (0.674). This finding is in line with Park's previous research. Park suggested that fixed construction period was very important for contractors and subcontractors to deliver the project [18].

Table 7 shows the value of squared multiple correlations. Typical output also displayed the squared multiple correlations for each measured variable. These values representing the extent to which a measured variable's variance explained latent factors.

Furthermore, from a measurement perspective, these loading factors represented how well an item measures a construct, and sometimes referred to as item reliability [23]. In additions, quality performance (x19) coefficient of 0.550 was the highest coefficient indicating how well construction quality measure the project success. On the contrary, contextual behaviors (x16) was the smallest coefficient of squared multiple correlations (0.198). It means that this variable did not measures a construct of stakeholder psychological empowerment quite well.

Baseline comparisons in Table 9 shows the TLI and CFI values. The most common baseline model was referred to as a null model, that asummed all observed variables uncorrelated. It implies that no data reduction can possibly improve the model because it contains no multi-item factors, which make any multi-item constructs or relationships between them impossible [23]. The figures 0.769 (TLI) and 0.820 (CFI) in Table 9 show that these values are closed to 0.900 which means that the model is fit.

\section{CONCLUSION}

Stakeholder's needs and requirements vary greatly depending on their involvement which influemce the project. Psychological empowerment exhibits positive performance behaviors which emerges as a valuable path in the search for performance improvement in project settings, however, this still requires cooperation and good teamwork. The result of this study seems consistent with the hypothesis that stakeholder psychological empowerment influenced the project success. Cronbach's Alpha coefficients of all the variables were well over the 0.70 minimum set by Nunally and indicated that the internal reliability of the constructs was quite high [22]. The Cronbach's Alpha coefficient of stakeholder psychological empowerment is 0.741 , and this value of project success is 0.796 .

The CFA of stakeholder psychological empowerment and project success is presented in Figure 2 and Figure 3 showed that all of the loading factors were significant at $\alpha=0.05$ and goodness of indexes indicated quite well. The final structural model presented in Figure 4 were significant at $\alpha=0.05$ and the goodness of indexes 0.769 for TLI and 0.820 for CFI indicated quite well. The reason why the indexes are not closer to perfect fit (are not higher than 0.90 for TLI and CFI) can be explained by the amount of sample size used in this study and by the fact there may be more than one variable laten stakeholder psychological empowerment that influence on project success.

The results of the structural equation modeling also suggested that there was a significant influence between stakeholder psychological empowerment and project success. Ability to perform was the important factor that influenced stakeholder psychological empowerment. It means that their employee's ability to perform contributes to reach the project success. This finding was in line with the previous research that ability to perform is mediator in the empowerment-performance relationship. Meanwhile, quality performance was found to be the greatest influencing factor on project success. It means that project managers should maintain the quality of the product to reach the successful project. Likewise, the previous study mentioned that quality performance can be used as a guide to measure the success of a 
project together with time performance and cost performance as iron triangle.

Limitation are unavoidable although extensive efforts were taken into this study. For giving the perfect model of project success, further study needs to be explored, not only emphasizing on stakeholders psychological empowerment, but also on understanding the role of the stakeholders.

\section{REFERENCES}

[1] S. Rowlinson and Y.K.F. Cheung, "Stakeholder management through empowerment: Modelling project success", Journal of Construction Management and Economics, Vol. 26, pp. 611-623, 2008.

[2] S.C. Certo, "Modern management", Prentice Hall, 1997, Vol. 7, New Jersey.

[3] Anonymous, "Consrtuction extension to the PMBOK®guide third edition", Project Management Institute, Pennsylvania, Vol. 2, pp. 19073-3299, 2008

[4] B. Atkin and M. Skitmore, "Stakeholder management in construction", Journal of Construction Management and Economics, Vol. 26, pp. 549-552, 2008.

[5] V.N. Marthur, A.D.F.Price, and S. Austin, "Conceptualizing stakeholder engagement in the context of sustainability and its assessment", Journal of Construction Management and Economics, Vol. 26, pp.601-609, 2008.

[6] S. Olander and A. Landin, "A comparative study of factors affecting the internal stakeholder management process", Journal of Construction Management and Economics, Vol. 28, pp.553-561, 2008.

[7] J.W. Newstrom and K. Davis, "Organizational behavior: Human behavior at work", Boston: McGraw Hill, 1997, Vol. 10.

[8] M.M. Tuuli and S. Rowlinson, "Performance consequences of psychological empowerment", Journal of Construction Engineering and Management (CASCE, Vol. 135, No. 12, pp.13341347, 2009.

[9] D.K. Ahadzie, D.G. Proverbs, and P.T. Olomolaiye, "Developing competency-based measures for construction project managers: Should contextual behaviours be distinguished from task behavoiurs?", International Journal of Project Management, Vol 26, pp. 631-645, 2008.

[10] H. Kerzner, "Project management: A systems approach to planning, scheduling, and controlling", New York: Van Nostrand Reinhold,1995, Vol. 5.

[11] A. Shtub, J.F. Bard, and S. Globerson, "Project management: engineering, technology, and implementation", Englewood Cliffs, NJ 07632: Prentice Hall International Inc., 1994.

[12] S.R. Toor and S.O. Ogunlana, "Beyond the "iron tiangle': stakeholder perception of Key Performance Indicators (KPIs) for large scale public sector development projects", International Journal of Project Management, Vol. 28, pp. 228-236, 2010.

[13] R. Takim and A. Akintoye, "Performance indicators for successful construction project performance", In: 18th Annual ARCOM Conference, Vol. 2, D. Greenwood, Ed., 2002, pp. 545-555.

[14] M.C. Achterkamp, and J.F.J. Vos, "Investigating the use of the stakeholder notion in project management literature, a metaanalysis", International Journal of Project Management, Vol. 26, pp.749-757, 2008.

[15] A.P.C. Chan, "Framework for measuring success of construction projects", School of Construction Management and Property Queensland University of Technology Brisbane, Australia, 2001.

[16] F.Y.Y. Ling, S.P. Low, S.Q. Wang, and H.H. Lim, "Key project management practices affecting singaporean firms' project performance in China", International Journal of Project Management, Vol. 27, pp. 59-71, 2009.

[17] A. Hamilton, "Management by projects. achieving success in a changing world, London : Thomas Telford, 1997.

[18] S.H. Park, "Whole life performance assessment: Critical success factors", Journal of Construction Engineering and Management (C)ASCE, Vol. 11, No. 135, pp.1146-1161, 2009

[19] R.B. Woodruff, and S.F. Gardial, "Know your customer:New approaches to understanding customer value and satisfaction", Blackwell Publisher, Inc, Cambridge, Massachusetts, 02142, USA 1996.

[20] The KPI Working, "KPI Report for the minister for construction", Department of the Environment, Transport and the Regions, 2000.

[21] R. Gerson, "Measuring Customer Satisfaction", Crisp Publications, Inc.Hamilton Count, Menlo Park, CA 94025-9600, USA, 1993

[22] Z. Izik, D. Arditi, I. Dikmen, and M.T. Birgonul, "Impact of Resources and Strategies on Construction Company Performance: Journal of Management in Engineering@ASCE, 26,1, pp.9-18, 2010

[23] J.F. Hair, W.C. Black, B.J. Babin, R.E. Anderson, and R.L. Tatham, "Multivariate Data Analysis", 6th ed. Pearson Prentice Hall, New Jersey 07458, 2006. 
TABLE 1.

CONSTRUCT AND MEASUREMENTS

\begin{tabular}{lll}
\hline Laten variables & \multicolumn{1}{c}{ CONSTRUCT AND MEASUREMENTS } \\
& \multicolumn{1}{c}{ Indicators } & Indicators \\
\hline Stakeholder & Motivation (x12) & {$[1-9]$} \\
Psychological & Opportunuty to perform (x13) & \\
Empowerment & Ability to perform (x14) & \\
& Task behaviors (x15) & \\
& Contextual behaviors(x16) & {$[10-21]$} \\
Project success & Cost (x17) & \\
& Time (x18) & \\
& Quality (19) & \\
& Profitability (x20) & \\
& Customer satisfaction(x21) \\
\hline
\end{tabular}

TABLE 3.

SUMMARY OF RESPONDENTS' TERM OF FIELD OF WORK, AND

\begin{tabular}{llll}
\hline Field of work & $\begin{array}{c}\text { Top } \\
\text { management }\end{array}$ & $\begin{array}{c}\text { Medium } \\
\text { management }\end{array}$ & $\begin{array}{c}\text { Lower } \\
\text { management }\end{array}$ \\
\hline $\begin{array}{l}\text { Owners } \\
\text { Construction } \\
\text { management }\end{array}$ & $8(3.92 \%$ & $30(14.71 \%)$ & $7(3.43 \%)$ \\
$\begin{array}{l}\text { consultants } \\
\begin{array}{l}\text { Designer } \\
\text { consultants }\end{array}\end{array}$ & $6(2.94 \%)$ & $4(1.96 \%)$ & $3(1.47 \%)$ \\
$\begin{array}{l}\text { Contractors } \\
\text { Subcontractors/ } \\
\text { suppliers }\end{array}$ & $27(13.24 \%)$ & $8(3.92 \%)$ & $8(3.92 \%)$ \\
& $14(6.86 \%)$ & $3(1.47 \%)$ & $2(0.98 \%)$ \\
& & & \\
\end{tabular}

TABLE 5.

REGRESSION WEIGHTS: (GROUP NUMBER 1 - DEFAULT MODEL)

\begin{tabular}{|c|c|c|c|c|c|}
\hline Variable & Estimate & SE & $\mathrm{CR}$ & $\mathrm{P}$ & Label \\
\hline $\begin{array}{l}\text { Project Success } \leftarrow \text { Empo } \\
\text { werment }\end{array}$ & 1.264 & 0.232 & 5.440 & $* * *$ & par_9 \\
\hline x16 Empowerment & 1.000 & & & & \\
\hline $\mathrm{x} 15 \leftarrow$ Empowerment & 1.020 & 0,211 & 4.821 & $* * *$ & par_1 \\
\hline $\mathrm{x} 14 \leftarrow$ Empowerment & 2.269 & 0.242 & 5.248 & $* * *$ & par_2 \\
\hline $\mathrm{x} 13 \leftarrow$ Empowerment & 1.154 & 0.241 & 4.781 & $* * *$ & par_3 \\
\hline $\mathrm{x} 12 \leftarrow$ Empowerment & 1.184 & 0.237 & 5.000 & $* * *$ & par_4 \\
\hline x $17 \leftarrow$ Project Success & 1.000 & & & & \\
\hline x18 & 1.180 & 0.155 & 7.617 & **** & par_5 \\
\hline x19 & 1.268 & 0.156 & 8.133 & **** & par_6 \\
\hline x $20 \leftarrow$ Project Success & 0.971 & 0.148 & 6.571 & $* * *$ & par_7 \\
\hline x $21 \leftarrow$ Project Success & 0.962 & 0.143 & 6.723 & $* * *$ & par_8 \\
\hline
\end{tabular}

TABLE 7.

SQuARED MultiPle CoRRELATIONS: (GROUP NUMBER 1 - DeFAult

\begin{tabular}{cc} 
& MODEL) \\
\hline Variable & Estimate \\
\hline x21 & 0.328 \\
x20 & 0.310 \\
x19 & 0.550 \\
x18 & 0.455 \\
x17 & 0.386 \\
x12 & 0.274 \\
x13 & 0.233 \\
x14 & 0.331 \\
x15 & 0.240 \\
x16 & 0.198 \\
\hline
\end{tabular}

TABLE 2.

SUMMARY OF RESPONDENTS' PROFILES

\begin{tabular}{lll}
\hline \multicolumn{1}{c}{ Field of work } & Total & Percentage \\
\hline Owners & 45 & $22.06 \%$ \\
Construction management & & \\
consultants & 13 & $6.37 \%$ \\
Designer consultants & 30 & $14.71 \%$ \\
Contractors & 97 & $47.55 \%$ \\
Subcontractors/suppliers & 19 & $9.31 \%$ \\
\hline
\end{tabular}

TABLE 4.

THE RESULTS OF VALIDATION AND RELIABILITY TEST

\begin{tabular}{lcc}
\hline \multicolumn{1}{c}{ Variables } & $\begin{array}{c}\text { Corrected item- } \\
\text { total correlation }\end{array}$ & $\begin{array}{c}\text { Cronbach's } \\
\text { Alpha if item } \\
\text { deleted }\end{array}$ \\
\hline Motivation & 0.510 & 0.813 \\
Opportunity to Perform & 0.466 & 0.818 \\
Ability to Perform & 0.564 & 0.807 \\
Task Behaviors & 0.479 & 0.816 \\
Contextual Behaviors & 0.431 & 0.821 \\
Cost & 0.521 & 0.812 \\
Time & 0.548 & 0.809 \\
Quality & 0.634 & 0.800 \\
Profitability & 0.496 & 0.814 \\
Customer Satisfaction & 0.508 & 0.813 \\
\hline
\end{tabular}

TABLE 6.

STANDARDIZED REGRESSION WEIGHTS: (GROUP NUMBER 1 - DEFAULT MODEL)

\begin{tabular}{lc}
\hline \multicolumn{1}{c}{ Variable } & Estimate \\
\hline Project Success $\leftarrow$ Empowerment & 1.000 \\
x16 $\leftarrow$ Empowerment & 0.445 \\
x15 $\leftarrow$ Empowerment & 0.489 \\
x14 Empowerment & 0.575 \\
x13 $\leftarrow$ Empowerment & 0.482 \\
x12 $\leftarrow$ Empowerment & 0.523 \\
x17 $\leftarrow$ Project Success & 0.622 \\
x18 $\leftarrow$ Project Success & 0.674 \\
x19 Project Success & 0.742 \\
x20 $\leftarrow$ Project Success & 0.557 \\
x21 $\leftarrow$ Project Success & 0.573 \\
\hline
\end{tabular}


TABLE 9.

\begin{tabular}{lccccc}
\hline \multicolumn{7}{c}{ BASELINE COMPARISONS } \\
MFI & RFI & IFI & TLI & CFI \\
Model & Delta 1 & Rho 1 & Delta 2 & Rho 2 & \\
\hline Default model & 0.775 & 0.711 & 0.823 & 0.769 & 0.820 \\
Saturated model & 1.000 & & 1,000 & & 1.000 \\
Independent model & 0.000 & 0.000 & 0.000 & 0.000 & 0.000 \\
\hline
\end{tabular}

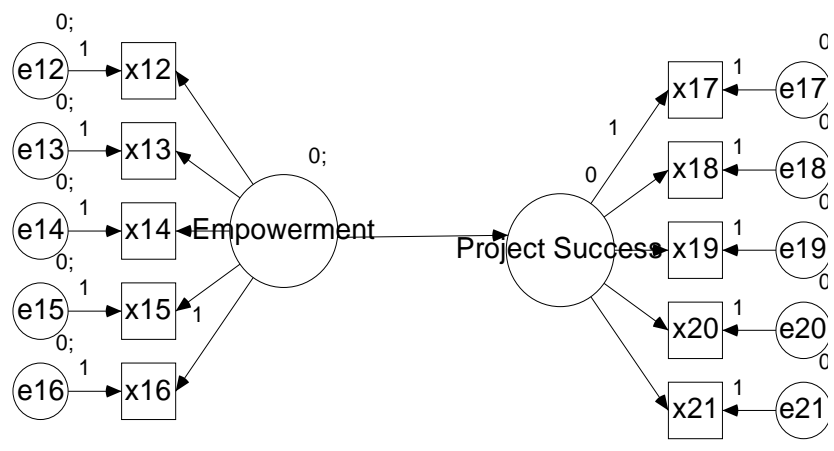

\section{Empowerment-Project Success}

Figure 1. Hypothetical model of stakeholder psychological empowerment and project success

Chi-Square $=24,482$

Prob=, 000

$\mathrm{DF}=5$

$\mathrm{CMIN} / \mathrm{DF}=4,896$

$T L I=, 869$

CFI $=, 935$
RMSEA $=, 139$

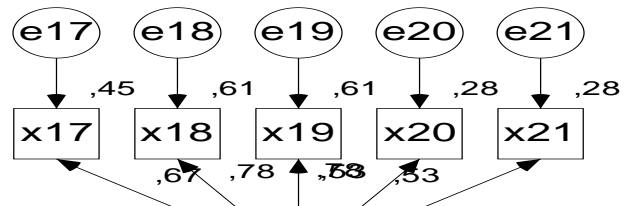

Project sucdess

CFA Project success 5 var

Figure 3. CFA project success
Chi-Square $=13,455$

Probability $=, 019$

$D F=5$

CMIN/DF $=2,691$

$\mathrm{CFI}=, 956$

RMSEA $=, 091$

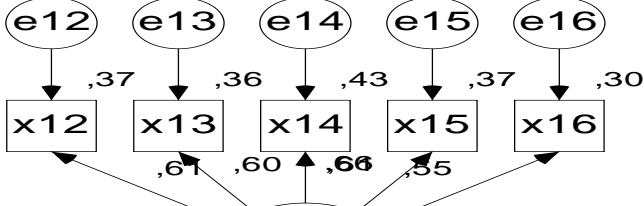

Empowerment

Figure 2. CFA stakeholder psychological empowerment
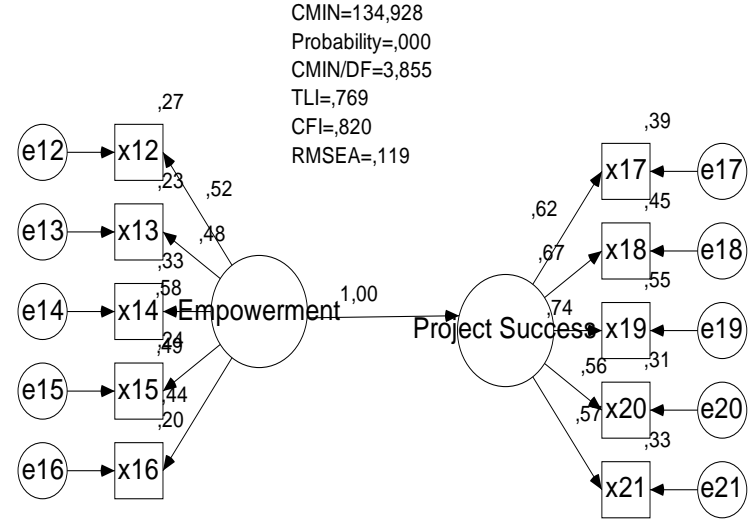

Empowerment-Project Success

Figure 4. Structural equation model for empowerment-project success 